\title{
Feminism without Philosophy: A Polemic
}

\author{
Jeremiah Joven Joaquin
}

\begin{abstract}
In this paper, I address the problem about the role of academic philosophy for the feminist movement. I argue that the professionalization of feminism, especially within the sphere of academic philosophy, is detrimental to the stated goal of the feminist movement, which, as historically understood, is to procure women's rights and liberties and to reassess the (oppressive) treatment of women by different social institutions. The thought is that if feminism were to reap the rewards of a socio-political change, feminists should stop their fantastic theorizing and start bringing their advocacies to the proper forums.
\end{abstract}

Keywords: feminism, feminist philosophy, feminist movement, feminist critique of philosophy

\section{Introduction}

In the beginning was the deed ... - Goethe, Faust

7 his is not an attack against feminism per se. It is rather an attack against the professionalization of feminism, especially within the sphere of academic philosophy. As historically understood, feminism is a movement devoted to procure women's rights and liberties and to reassess the (oppressive) treatment of women by different social institutions. Given the idea that the stated goal of feminism is to effect social-political changes, this paper argues that in order for feminism to achieve this, it ought to cease its incessant attempt to form a foundation, or explanation, or even theory of how and why such oppression came about. That is, if feminism were to reap the rewards of a socio-political upheaval, feminists should stop their fantastic theorizing and start to bring their advocacies to the proper forums.

It must be emphasized that I am not suggesting that feminist philosophers should stop philosophizing. On the contrary, their critique of

(c) 2016 Jeremiah Joven Joaquin

http://www.kritike.org/journal/issue 18/joaquin june2016.pdf

ISSN 1908-7330

(cc) $\mathrm{BY}-\mathrm{NC}-\mathrm{ND}$ 
philosophy is one of the catalysts for some philosophers to become iconoclasts in their way of doing philosophy. The danger that I am presenting, rather, is in too much theorizing. This danger can and will cause a trivialization or de-radicalization of feminism. Proponents of the feminist cause to effect socio-political change in favour of women would be accused of elitism if they were to stick with their highfaluting theorizing.

My suggestion is pure and simple: Feminism should take care of itself. That is, its proponents should be careful not to overstep the boundaries of discourse. If they were to achieve some concrete changes in the treatment of women in every facet of human living, then they better stick with the issues concerning women. It is not our theories that will determine whether there are women being oppressed; rather, it is the fact that we see them being oppressed. The argument that I will present in favour of my view can be stated in just five words: Too much talk is useless.

\section{A Sketch}

As we have seen from the above discussions, I have arrived at a problem that I wish to tackle in this essay. I formulate the problem as follows: Does feminism, as a socio-political movement, need to have a philosophy concerning the nature of gender inequality? And would feminism achieve its main socio-political concerns by giving philosophical foundations for them?

This problem can be felt more if we are to set an analogy for it. Consider the following issues: first, whether we must have a theory of aesthetics in order for us to have a social policy that prohibits throwing chewing gum waste; second, whether we should speculate on the mechanistic tendencies of "culture" in order to have an economic policy against inhumane treatment of labourers. If you answer affirmatively to both cases, then I resign my argument. However, appealing to my intuition, I would bet that you would take a negative stance concerning the first issue, and that you would give a not-so-straightforward answer to the second. Through the course of the discussion, I will explain why you would go for these options.

The first issue is a no-contest. No one in his or her right sense of mind would assert that there must be a theory of what is beautiful in order to make policies on cleanliness. ${ }^{1}$ That is, it is not a necessary condition for such a policy to have an underlying theory of aesthetics. For we can surely device a

1 The referee has pointed out that one could make the argument that a theory of aesthetics might inform a general policy about sanitation. I agree with this. But the issue that I am pointing out here is whether it must inform such policies. Like most people, I would go for a negative answer, namely, that an aesthetic theory is not necessary to make policies about sanitation.

(c) 2016 Jeremiah Joven Joaquin

http://www.kritike.org/journal/issue 18/joaquin june2016.pdf

ISSN 1908-7330 
different set of conditions that could necessitate the need for such a policy. We could perhaps offer the fact that in some instances of environment pollution, infectious diseases occur. This implies that if we are to avoid these diseases, we better clean up. The condition that was offered, namely, that infectious diseases might occur if we have a polluted environment, can be taken as a reason for making a policy against pollution. The theory of beauty that seems to be necessary a while ago now vanishes into thin air. Of course, you may agree with this kind of reasoning for this issue. However, you may disapprove of its use to the second issue.

The second issue is a conjoining of two elements. On the one hand, there is our speculation about the mechanistic tendencies of "culture." On the other hand, there is the need to make a policy against the inhumane treatment of labourers. If we were to argue in favour of making such a policy and if we were to give the condition that there is a mechanistic tendency found in our "culture" that dictates our behaviour towards our fellow human beings, then the conclusion is that the policy that we will make must assent to the mechanistic tendency. But wait! Isn't this contrary to the policy that we want to achieve? If we were to say that we need a policy against the ill-treatment of labourers, then we should support this policy by asserting that such injustices are wrong. But if we are to find our reason for the claim that such injustices are wrong in the mechanistic tendency of our "culture," we are lost in the argument. That there are labourers dying because of inhumane treatments-which we could ascertain just by looking at their work environment-is reason enough, I think, to make a policy against it.

Surely now, you might remark, there must be a theory that backs up the claim that there are injustices in the work environment. To this I will reply that yes, there surely can be a theory behind our judgment of what is an unjust treatment of human beings. But if you press to know more about it, I can go on further and talk about the different theories of justice since time immemorial. However, we might be taken aback once we see the labourer lying half-dead in the corner where we are speculating novel and philosophical ideas.

How we use our critical reason, our philosophical mind, in order to address these two issues shows how we use the god-given talent of thinking. There is nothing wrong with thinking about some social issue. In fact, it is always advisable to think through an issue before we make decision about it. All possible permutations and implications of the problem must be addressed before we could arrive at a viable position and course of action. The problem, however, is when we fail to focus on the issue itself, when we let our thoughts fly towards the sky, and when we leave the issue unanswered. Well, you might think that this is what philosophizing really entails. I will again second your observation here. But the point of effecting policies is that they must

(c) 2016 Jeremiah Joven Joaquin

http://www.kritike.org/journal/issue 18/joaquin june2016.pdf

ISSN 1908-7330

(c) $)$ BY-NC-ND 
address particular issues. If we are to make policies that can address this, then we must control our tinkering minds. Philosophical thinking is helpful, but it can, at times, be disruptive in achieving particular ends.

The discussion that I have presented so far is a preliminary sketch of what I will present in the remainder of the paper. I do hope that what I have presented has given you a glimpse of my general argument throughout. In the next sections, I aim to discuss the following under their respective headings:

- Feminism as a Movement, where I will present what feminism, as a movement, would like to achieve in its advocacy for women's rights;

- Feminism as a Critique, where I will focus on the effect of the feminist critique in the academe, especially in philosophy;

- Feminism with/without Philosophy, where I will represent some of the dangers of too much speculation in feminism and how this affects their advocacy; and, finally,

- Feminism in the Public Sphere, where I will present my conclusion and restate my recommendations for the feminist cause.

\section{Feminism as a Movement}

The unfolding of the history of feminist ideals from Plato-although this may be debatable-down to the present is still a work in progress. Amidst this long and often turbulent unfolding, feminist ideals still hold water for modern advocates of feminism today. What are these ideals? Currie and Kazi tell us that:

Despite the diversity of its arguments, feminism is unified through its challenge to male power and by its vision of an alternative society; one freed from inequalities based on sex and gender. ${ }^{2}$

From this, we can say that feminism envisions a society where one is freed from oppression caused by gender and sex inequalities ${ }^{3}$ and where all human beings (male and female alike) live harmoniously in one and the same world. I am not sure if I have formulated the second conjunct as well as most feminists would. But the point of these ideals is to give to humanity (not in

\footnotetext{
2 Dawn Currie and Hamida Kazi, "Academic Feminism and the Process of DeRadicalization: Re-Examining the Issues," in Feminist Review, 25 (1987), 77.

${ }^{3}$ As the referee has pointed out, there is a huge, albeit misguided, feminist literature about the "philosophical" issue of whether sex and gender are natural categories, or merely socially constructed ones. And to some extent I agree with this general indictment.

(c) 2016 Jeremiah Joven Joaquin http://www.kritike.org/journal/issue 18/joaquin june2016.pdf ISSN 1908-7330 
the gendered sense of the term) their liberty back, that is, the liberty to choose for ourselves the determination of our lives.

A survey of all feminist positions throughout the ages would not suffice to support the assumption that all feminists yearn for this ideal. Several feminists would in fact repudiate this, stating that the idea of equality is, in itself, a male-construct. Or that there are no real distinctions between sexes; our distinctions are merely creatures of fiction. Be that as it may, if we look at the history of feminism, we could see that the main themes and persuasions of each "school" of feminism are instructive to discern a univocal ascription of their aspiration, which is the recognition of the Other (the woman) as a person that is part of the same world.

Towards the end of the age of enlightenment, new voices can be heard resonating as one voice, calling the world to recognize women's right to vote. The right to vote gave rise to a movement known as the Suffragettes, whose advocacy was to ensure that women, as citizens of a state, were given the same rights and privileges offered to their male-counterparts. The advocacy for the right to vote was only the beginning for the feminist call for equal distribution of rights and liberties.

Another advocacy put forward was the right to equal opportunity in education. And yet another is the equal opportunity to work. These advocacies were the foundations of feminism as a social force. There were many noble heroes and heroines that stood up in the late nineteenth century. Noble names such as John Stuart Mill, Harriet Taylor, Mary Wollstonecraft, and many others can be presented as advocates of women empowerment. Thus, a movement was born: the feminist movement.

Rhode envisions three central commitments of feminist cause (be it on a political, philosophical, or practical field) $)^{4}$

1) On a political level, they seem to promote equality between men and women;

2) On a substantial level, feminist critical frameworks make gender a focus of analysis; their aim is to reconstitute legal practices that have excluded, devalued, or undermined women's concerns; and,

3) On a methodological level, these frameworks aspire to describe the world in ways that correspond to women's experience and to identify the fundamental social transformations necessary for full equality between the sexes.

${ }^{4}$ Deborah Rhode, “Feminist Critical Theories," in Stanford Law Review, 42:3 (1990), 619.

(c) 2016 Jeremiah Joven Joaquin

http://www.kritike.org/journal/issue 18/joaquin june2016.pdf

ISSN 1908-7330

(c) BY-NC-ND 
These commitments, Rhode continues, are mutually reinforcing. But because of differences in persuasions, they do, in some occasions, pull in different directions. These "directions" are the so-called feminist theories.

If we were to advocate for the rights and liberties of women, we would be called feminists. However, the label "feminist" is full of unnecessary conceptual baggage that often people regret being called as such. For example, Schnittker, Freese, and Powell remarked:

Despite increasing support for many feminist ideals, negative sentiments toward the label "feminists" remain strong and many individuals who embrace seemingly feminist positions nonetheless deny that they are feminists. $^{5}$

Now, we may ask: Why is this? It may be, following these authors still, that the label "feminist" has the connotation of an ideology. Upon hearing the term "ideology," people may start to think about the horrors that Marx, Hitler, and Stalin have impacted in history because of their respective ideologies. This is why, as Misciagno considers, this is a paradox for contemporary feminism. ${ }^{6}$ On the one hand, people may advocate the same ends as the feminist, but because of the added stigma of being an ideologywhich I think feminism, as a socio-political movement, is not-some people may say that "I am a feminist, but ...." Whatever is at the end of that statement would surely counteract the reaction the first statement already induced to the hearer.

It is somewhat depressing to think that feminism as a socio-political movement, which promotes equality of men and women, advocates the rights and liberties of women, and criticizes the oppression caused by the idea of gender hierarchies, would be tainted by a stigma as bad as Marx's, Stalin's, or Lenin's. All we can do now is to ask: Why did feminism come to such a situation?

\section{Feminism as a Critique}

In the preface to his Critique of Pure Reason, Kant tells us that:

\footnotetext{
${ }^{5}$ Jason Schnittker, Jeremy Freese, and Brian Powell, "Who are Feminists and What Do They Believe? The Role of Generations," in American Sociological Review, 68:4 (2003), 607.

${ }^{6}$ Patricia Misciagno, Rethinking Feminist Identification: The Case for De Facto Feminism (Westport, CT: Praeger Publishers,1997), xviii.
}

(c) 2016 Jeremiah Joven Joaquin http://www.kritike.org/journal/issue 18/joaquin june2016.pdf

ISSN 1908-7330 
It is, in fact, a call to reason, again to undertake the most laborious of all tasks - that of self-examination - and to establish a tribunal, which may secure it in its wellgrounded claims, while it pronounces against all baseless assumptions and pretensions, not in an arbitrary manner....7

Following Kant's advice, a re-examination of our discipline itself, i.e., the discipline of academic philosophy, should be undertaken so that we can purposely go on to other inquires without guile or deceit to ourselves.

But alas! When philosophers, especially feminist philosophers, turned their lenses inward and looked upon the canonical works in philosophy they have seen, to their dismay, that there were misogynist remarks present, and often highlighted, by notable philosophers. But should it really be a cause of dismay to find such elements present in those works? For any self-respecting philosopher, it should be. After thousands of years of transmitting this body of knowledge from one hand to another, why did it not occur to these male philosophers that something is wrong here?

There are various examples of these misogynistic remarks in the philosophical canon. We see this in Aristotle, the father of systematic philosophizing, who, in the Politics, remarked that "the male is by nature fitter for command than the female." We see this in Aquinas when he said that "women are incomplete men." Certainly, these pronouncements send some mixed signals. Aristotle and Aquinas, after all, are looked up to as brilliant philosophers. But though brilliant, they still look at women as second-rate beings.

You might reply that we should be fair to these philosophers since they were a product of their time and situation. And their views might have been informed by their cultural milieu. ${ }^{8}$ After all, Aristotle was a product of the Hellenistic tendency to downgrade women, while Aquinas was a product of the medieval aspiration to cleanse man of his earthly desires. To this I reply, yes they were a product of their time, but after hundreds of years of scholarship, why did people not see these misogynistic messages? Or did they see it but failed to look? Why, if they had looked, did they not do something about it? Or why did they not even discourse about its ramifications?

But it is not only scholars of the past that should be blamed. We, as scholars of today, should be blamed as well. Most of us are still unaware of these misogynistic writings. Or if we are aware, some of us are still not doing

7 Immanuel Kant, Critique of Pure Reason, trans. by J.M.D. Meiklejohn, rev. and expanded by Vassilis Politis (London: Everyman, 1993), 5 [A/1781, xi].

${ }^{8} \mathrm{I}$ acknowledge the referee for pointing this out.

(c) 2016 Jeremiah Joven Joaquin

http://www.kritike.org/journal/issue 18/joaquin june2016.pdf

ISSN 1908-7330

(cc) BY-NC-ND 
something about it. As such, both the present and past scholars of philosophy have the same moral standing with regard to the failure to address genderbias in our canons.

It is the task of a critique, still following Kant, to give appraisals to well-reasoned claims and to pronounce against those which are grounded on baseless assumptions. To paraphrase Wittgenstein, philosophy should take care of itself. And this process of assessment is where the feminist critique of philosophy has its glory. As Seller said, "we owe a great deal to feminists who have, through rigorous intellectual effort, revealed that much purportedly impartial and objective scholarship and science is grounded in male bias." ${ }^{9} \mathrm{I}$ personally think that the feminist critique, which focused on the gendered elements in the way philosophers do philosophy, helps in the facilitation of libertarian ideas, which can be traced from Kant-or still quite farther down the line to Locke. Their commentary against the grounding of philosophical principles-e.g., Rousseau's suggested formula for women education-to baseless assumptions of sex and gender hierarchies is a stroke of ingenuity and would, in the long run, result in the betterment of philosophical inquiry.

We have many heroines to thank for this. We have Charlotte Witt, Sandra Harding, Martha Nussbaum, Mary Warnock, Janet Richards, and Helen Logino to thank. And I can assure you that there are many more people to thank for their efforts. The task is indeed hard, but someone has to start it. And, in fact, some already did.

Amidst the glories of the feminist critique of philosophy, there are also some that drove their critique to the edge. This led to a hyper-critical, or even a hypocritical, critique. And these eventually led to the ascription of feminism not as a positive movement that criticizes gender hierarchies and promotes the rights and liberties of women, but as an ideology that promotes advocacies that simply serve their particular persuasions.

\section{Feminism with/without Philosophy}

It is imperative to make a distinction between the two uses of the term "feminism" in order to eliminate the stigma of ideology in feminism. Richards makes a clear distinction between feminism as a rigid doctrine and feminism as a belief about sexual inequality. ${ }^{10}$ Of course, the former use is associated with feminism as an ideology, while the latter is associated with feminism as a socio-political movement. The importance of this distinction

9 Anne Seller, "Realism versus Relativism: Towards a Politically Adequate Epistemology," in Feminist Perspectives in Philosophy, ed. by Morwenna Griffiths and Margaret Whitford (Indianapolis, IN: Indiana University Press, 1988), 170.

${ }^{10}$ See Janet Richards, The Sceptical Feminist: A Philosophical Enquiry (Harmondsworth: Penguin, 1980).

(c) 2016 Jeremiah Joven Joaquin

http://www.kritike.org/journal/issue 18/joaquin june2016.pdf

ISSN 1908-7330

(cc) BY-NC-ND 
was already touched on in the previous discussions. But it will figure again in our later explorations.

But we need to ask: Why is it necessary to eliminate the stigma of ideology from feminism? To answer this, still following Richards, we must point out that if feminism is construed merely in terms of an ideology of a certain "type of people" (women-type, of course), it will prevent a critical reassessment of the ideas of feminism by feminists themselves. For accepting an ideology implies closing down points of inquiry, and since healthy and open points of inquiry lead to critical reassessment, it follows, therefore, that feminism construed as an ideology implies nothing but dogmatism.

While dogmatism resists any change in the status quo and feminism, as a belief about sexual inequality, implies a direct attempt to make changes in the status quo, then it follows that feminism construed as a belief about sexual inequality can never be a dogmatist. ${ }^{11}$ However, since the use of the term "feminism" is closely associated with ideology, it would follow that the very conception of feminism as a belief in sex and gender inequality leads to a contradiction that will hinder the fulfilment of the socio-political changes that women, general, want to achieve. This result is inevitable if we are not careful with interplay of the uses of the term "feminism."

The importance of making the distinction between the two uses of the term "feminism" is that amidst the term's association with ideology, a greater and more significant issue is at stake, and that is the de-radicalization of the advocacies of feminism. As I have pointed out, feminism bore out from the struggle of women to achieve equal rights and liberties. This marks the start of feminism as a movement driven by the belief that there is something wrong with the status of women in society. The idea of equal rights for men and women and the idea of making political upheavals are radical ideas. However, due to the insistence of some theorists to create deeper philosophical foundations for the genesis of the struggle of women or the gender hierarchical model, feminism rose from being a political movement that promotes women's rights to being an academic ideology, which focuses more on intellectual matters that only she and her cohorts could appreciate.

From the fashionable corridors of the academia, we might see a feminist philosopher in her academic gown discussing in highfaluting jargons why the word "womyn" is a better label than "women." 12 Perhaps, we might also see them (the academic feminists) discussing the ontological status of social constructs such as sex, gender, and gender roles. Or perhaps, we might see the elaborate demonstrations by a well-known French feminist explaining her views on the inadequacy of the bipolarity of the

\footnotetext{
11 The contrapositive, of course, also follows.

${ }^{12}$ Again, my thanks to the referee for this wonderful example.
}

(C) 2016 Jeremiah Joven Joaquin

http://www.kritike.org/journal/issue 18/joaquin june2016.pdf

ISSN 1908-7330

(c) BY-NC-ND 
epistemological concatenations that grilled the hybrid array of Otherness in the whole warmth of being.

Currie and Kazi drive the point home when they remarked:

... [T]he radical ideas of feminism have been transformed into an academic debate which no longer has relevance for women outside the hallowed halls of institutional life ... ideas inspired by feminism have become separated from feminism as a social movement and at this point lose their potential for change... [the] ideas of feminism have been 'de-radicalized,' supporting status quo rather than working to undermine it. ${ }^{13}$

Bowles and Klein offer a slightly different take on the issue I am trying to set: “... differences within academic feminism merely reproduce hierarchies and create new divisions - this time between women." 14 But they have the same sentiments about too much academic philosophizing by feminists by pointing out that “...women's studies may become a new road to elitism: writing and thinking time for the privileged few, this time for white, middle-class women." ${ }^{15}$ Furthermore, Stanley and Wise make the same point that "... this 'special relationship' prevents the participation of all feminists in the production of 'feminism'." 16

When feminism entered into the realm of academia (and this was around the late 1960's and the early 1970's), it was hoped that they would make the cause of women more apparent to a new generation. Alas! The case was different. What happened was feminism developed into an ideology that needs philosophical grounding. Yearning for a foundation is the battle cry of these feminists. I am not going to point any finger at whoever is the culprit of this phenomenon. All I am saying is that feminism did not start out as an ideology. It started out as a political movement for social change. But from this, it grew into one.

As it became more and more fascinated with explaining phenomena, the feminist ideology permutated and mutated into different species. It is mind blowing to consider that feminism as a theoretical academic endeavour happened only in the past 50 years. I say the root of all of this is the insistence

\footnotetext{
${ }^{13}$ Currie and Kazi, "Academic Feminism," 77.

14 Bowles and Klein (1983, 131). Gloria Bowles and Duelli Klein, eds., Theories of Women's Studies (London: Routledge and Kegan Paul, 1983), 131.

${ }^{15}$ Ibid.

${ }^{16}$ Liz Stanley and Sue Wise, Breaking Out Again: Feminist Ontology and Epistemology (London: Routledge, 1993), 54.
}

(c) 2016 Jeremiah Joven Joaquin http://www.kritike.org/journal/issue 18/joaquin june2016.pdf ISSN 1908-7330 
of some feminists to present feminism not as a catalyst for socio-political change, rather, as a body of doctrines about the primacy of anti-essential matter that permutated into a labyrinth of anomalies. (I' $m$ being ironic here, of course).

If we try to evaluate the status of feminism as a philosophical enterprise, we would miss the point of what feminism can offer to the philosophical gourmet. Feminism offers a critique of philosophy in terms of the gravity of gender bias. Feminism also raised come curious points in the field of political philosophy and ethics. These are areas where they can present their case. I need to emphasize the idea that feminism is not a branch of philosophy (like metaphysics or epistemology). Nor is it a complete body of doctrines that we need to take whole sale. (It is not a bible.)

Feminism, rather, is like a nice pair of sunglasses that we need to wear from time to time in order to see things differently. It is a method in philosophy that tries to point out that there are some great works by philosophers which are loaded with gender insensitivity. It tries to let you see, as Richards did, that there are women who suffer from systematic social injustices just because they are women. ${ }^{17}$ The goal of feminism as a movement, as Currie and Kazi stated, is to eliminate this type of injustice. ${ }^{18}$ And, of course, this is something which women and men alike should want to eliminate.

Feminism is a movement that advances the causes of women, a movement that aims to effect social change in the status quo. But given this, one might now ask, where and how should feminists advance their aims? Should it be in the academe? Should it be by becoming philosophers?

\section{A Conclusion: Feminism in the Public Sphere}

Consider this dialogue:

A: Where do we effect the changes that feminism advocates?

B: Well, this is easy to answer; of course, we need to effect these changes in the proper venues.

A: But what are the proper venues?

B: Well, it depends on what changes you would want to effect. If you want to change some company policies concerning pregnant

17 See Richards, The Sceptical Feminist.

${ }^{18}$ See Currie and Kazi, "Academic Feminism."

(C) 2016 Jeremiah Joven Joaquin

http://www.kritike.org/journal/issue 18/joaquin june2016.pdf

ISSN 1908-7330

(c) BY-NC-ND 
employees, you should see your employer. Now if you want to make this policy into a law so that all women can benefit, then you should go to lawmakers.

A: But why should we trust those people? They won't understand what a woman feels. They won't even bother hearing me out. The only thing left for me is to physically fight for what is rightfully mine.

B: Thousands of years have already passed and we still have not learned anything. We still opt to fight. Don't you know that we already have institutions that can do a pretty good job for our benefit?

A: But are all those people in those institutions really trustworthy?

B: I did not say that. I only said that we have institutions. I don't even believe that most people in those institutions are doing their job right. What I am vouching for is that we have those institutions already. And we can turn to them to help address our needs.

A: Women should rule those institutions. Unless women do so, we cannot effect the changes that we want.

\section{B: Well, I don't know about that.}

Feminism is a movement geared towards the emancipation of women from oppression due to sex and gender biases. It is a movement that promotes the welfare and rights of women. But how do we go about creating a climate of social cohesion among men and women.

MacKinnon points out that women cannot wait until all the spheres that procure social change are in their control. "If women are to restrict our demands for change in the spheres we can trust, spheres we already control, there will not be any." 19 To effect social change, especially the changes feminism wants, the proper venue would be the courts of law, the house of congress, or even the streets.

The right venue for feminists to address their concerns might not be in the hallowed walls of the academe where they will likely be tainted with the stigma of ideological speculation. If feminism is still considering itself as a movement geared towards creating a just and liberal society where women have equal rights and opportunities, then perhaps the public sphere is where

${ }^{19}$ Catharine MacKinnon, Feminism Unmodified: Discourses on Life and Law (Cambridge, MA: Harvard University Press, 1987), 228.

(c) 2016 Jeremiah Joven Joaquin http://www.kritike.org/journal/issue 18/joaquin june2016.pdf

ISSN 1908-7330 
these demands are worth presenting. The openness of discussion in such a venue results in positive action (or inaction, depending on the policy being discussed). If results are what we are after as feminists, we need policies. And since policies can only be achieved in the proper forums, it is imperative for feminist proponents (be they be men or women) to go back to the streets and make their hands dirty.

But there are still a lot more to discuss concerning women welfare aside from the issue of rights and liberties. As Coultas explains:

Modern feminism cannot avoid taking part in \{that\} discussion and in the process we will be forced not only to re-evaluate our own success and failures, but also our attitude as a movement to the entire spectrum of political opinions $\ldots{ }^{20}$

What is the \{that\} that Coultas is referring to? There are many problems besetting a feminist: problems concerning pornography, women exploitation, abortion, issues on women employment, sexual harassment, women oppression, rape, violence against women, etc. These issues are not resolved by setting up foundational theories. These are facts that we need to combat. We can speculate how to combat them, what methods could be used, what the implications of these methods will be, or what the implications of not doing anything about it could be. Yes, we can speculate. But our speculation should lead to a positive resolution.

If all we are going to talk about are matters proper only for philosophers, then talk about them. But that is all that can happen: an exchange of saliva. Yes, this salivating can raise awareness and clarify certain pertinent issues. That's what intellectual discussions are for anyway. But if feminists want change, mere talk is not enough. What are needed are changes in the socio-political make-up of society. And where can we do this? There are a lot of venues as I have said. But there is an institution where, in fact, it has already been done, that is, in civil law.

Civil law, MacKinnon says, is more effective. In a discussion, Jeffries and MacKinnon narrated how effective civil law is to effect socio-political change. ${ }^{21}$ MacKinnon was asked to represent some raped Bosnian and Croat women in a lawsuit against Radovan Karadzic. The result has been Kadic v Karadzic, and MacKinnon is very proud of the result of this case because it set the justice system rolling against sex-slave trade. The victims were

\footnotetext{
${ }^{20}$ Val Coultas, "Feminists Must Face the Future," in Feminist Review, 7 (1981), 35.

${ }^{21}$ Stuart Jeffries and Catharine MacKinnon, "Are Women Human? An Interview with Catharine MacKinnon," in The Guardian (12 April 2006), $<$ https://www.theguardian.com/world/2006/apr/12/gender.politicsphilosophyandsociety $>$.
}

(C) 2016 Jeremiah Joven Joaquin http://www.kritike.org/journal/issue 18/joaquin june2016.pdf ISSN 1908-7330 
awarded $\$ 745 \mathrm{M}$. The money was used to establish an organization that provides support for victims of sex offenders. These are two forms of civil relief that actually could make a change in the situation. That they could make such a difference is the most important thing.

In conclusion, I say again that in order for the ideal of feminism (taken as a socio-political movement) to have concrete results in effecting socio-political changes, philosophical systems need not be built. Effecting socio-political changes happens in a proper forum. That proper forum happens in the public sphere (e.g., in civil law). However, quoting a reviewer of MacKinnon's work, "we must be aware of the limitations of the state and of the law; the law is not everything, but it is not nothing either." 22 We have our public institutions where we can raise our concerns about women's welfare, rights, and issues. Yes, they are limited in their functions. But let this not deter us from using them to achieve the ends that we want. That there is women oppression-due to a baseless premise called gender inequality -is reason enough to ask for social change in proper forums in the public sphere. ${ }^{23}$

Department of Philosophy, De La Salle University-Manila, Philippines

\section{References}

Bart, Pauline, Review of Catharine MacKinnon, Feminism Unmodified:

Discourses on Life and Law, in The American Journal of Sociology, 95:2

(1989).

Bowles, Gloria and Renate Duelli Klein, eds., Theories of Women's Studies

(London: Routledge and Kegan Paul, 1983).

Coultas, Val. "Feminists Must Face the Future," in Feminist Review, 7 (1981).

Currie, Dawn and Hamida Kazi, "Academic Feminism and the Process of

De-Radicalization: Re-Examining the Issues," in Feminist Review, 25

(1987).

\footnotetext{
22 Pauline Bart, Review of Catharine MacKinnon, Feminism Unmodified: Discourses on Life and Law, in The American Journal of Sociology, 95:2 (1989), 538-539.

${ }^{23}$ A version of this paper was delivered in 2009 at the Ethics Conference held at Adamson University, Manila, Philippines. I would like to thank the organizers and participants of that conference for their helpful comments. My special thanks to my wife, Maria Georgina Joaquin, and my colleagues, Robert James Boyles, Mark Anthony Dacela, and Napoleon Mabaquiao for their constant support and encouragement. I acknowledge Noelle Leslie dela Cruz for the discussions that helped form the basis of this paper, and the anonymous referee for some very useful suggestions.
}

(c) 2016 Jeremiah Joven Joaquin http://www.kritike.org/journal/issue 18/joaquin june2016.pdf

ISSN 1908-7330 
Griffiths, Morwenna and Margaret Whitford, eds., Feminist Perspectives in Philosophy (Indianapolis, IN: Indiana University Press, 1988).

Jeffries, Stuart and Catharine MacKinnon, "Are Women Human? An Interview with Catharine MacKinnon," in The Guardian (12 April 2006), $<$ https://www.theguardian.com/world/2006/apr/12/gender.politicsp hilosophyandsociety>.

Kant, Immanuel. Critique of Pure Reason, trans. by J.M.D. Meiklejohn, rev. and expanded by Vassilis Politis (London: Everyman, 1993).

MacKinnon, Catharine, Feminism Unmodified: Discourses on Life and Law (Cambridge, MA: Harvard University Press, 1987).

Misciagno, Patrica, Rethinking Feminist Identification: The Case for De Facto Feminism (Westport, CT: Praeger Publishers, 1997).

Rhode, Deborah, "Feminist Critical Theories," in Stanford Law Review, 42:3 (1990).

Richards, Janet, The Sceptical Feminist: A Philosophical Enquiry (Harmondsworth: Penguin, 1980).

Schnittker, Jason, Jeremy Freese, and Brian Powel, "Who are Feminists and What Do They Believe? The Role of Generations," in American Sociological Review, 68:4 (2003).

Seller, Anne, "Realism versus Relativism: Towards a Politically Adequate Epistemology," in Feminist Perspectives in Philosophy, ed. by Morwenna Griffiths and Margaret Whitford (Indianapolis, IN: Indiana University Press, 1988).

Stanley, Liz and Sue Wise, Breaking Out Again: Feminist Ontology and Epistemology (London: Routledge, 1993). 